\title{
Does Framing Matter for Conditional Cooperation? Evidence from a Natural Field Experiment*
}

\author{
Stephan Meier
}

\begin{abstract}
Framing a decision situation differently has affected behavior substantially in previous studies. This paper tests a framing effect in a field experiment at the University of Zurich. Each semester, every student has to decide whether to contribute to two social funds. Students were randomly informed that a high percentage of the student population contributed (or, equivalently, that a low percentage did not contribute), while others received the information that a relatively low percentage contributed (or a high percentage did not contribute).

The results show the influence of framing effects is limited. People behave in a conditional cooperative way if informed either about the number of contributors or about the equivalent number of non-contributors. The positive correlation between group behavior and individual behavior is, however, weaker when the focus is on the defectors. The field experiment also shows gender differences in social comparison.
\end{abstract}

KEYWORDS: Field Experiment, Charitable Giving, Social Comparison, Framing, Gender

\footnotetext{
* Kennedy School of Government, Harvard University; and Research Center for Behavioral Economics and Decision-Making, Federal Reserve Bank of Boston, 600 Atlantic Avenue, Research T-8, Boston, MA 02210; e-mail: stephan_meier@ksg.harvard.edu. I am grateful for helpful comments from Iris Bohnet, two anonymous referees and John List, the editor of this special edition. I thank the administration of the University of Zurich, especially Thomas Tschümperlin, for their support of the project. I also thank the Swiss National Science Foundation for their financial support. I wrote this paper while I was a visitor at the Kennedy School of Government at Harvard University, and would like to acknowledge their generous hospitality. The views expressed herein are solely those of the author and not those of the Federal Reserve System or the Federal Reserve Bank of Boston.
} 
Suppose you are listening to your favorite National Public Radio channel while driving to work, and happen to hear the following ad: "Good Morning Boston, most of you who are tuned into and listening to our broadcasting station do not contribute towards its costs. Please show your appreciation and support of our broadcasting station by donating some money. Call 1-800-SUPPORT-US”. What are the chances that you contribute to the NPR after this solicitation campaign? Would your willingness to contribute be different if the ad were to say: "Good Morning Boston, most of you who are tuned into and listening to our broadcasting station do contribute towards its costs. Please show your appreciation and support of our broadcasting station by donating some money. Call 1-800-SUPPORT-US"?

The information given in the two examples above differ with respect to two crucial aspects, (1) the average group behavior, and (2) whether people are focused on the number of contributors or the number of non-contributors.

(1) Average Group Behavior and Conditional Cooperation. The examples differ in the information concerning how many others contribute to the NPR station. ${ }^{1}$ In the first example, potential donors get the information that only a few people contribute to the public good, whereas in the second example they are informed that many people do so. The behavioral predictions about whether this information increases or decreases people's willingness to contribute depends on which theory you rely on. If people behave as pure altruists, they should decrease their contributions if they observe that many others are already contributing (e.g. Clotfelter, 1997). However, people might behave pro-socially, depending on the average behavior in their reference group. One potential explanation for this behavior could be that people take the descriptive norm (what others do) as a signal for the injunctive norm (what is socially approved) (Cialdini, Reno and Kallgren, 1990). People might then perceive the public good situation as a coordination game and react positively to the information that others contribute as well (see Bohnet and Cooter, 2004). People's willingness to contribute to a public good therefore increases if they are informed that others do so as well. ${ }^{2}$ The empirical evidence favors the second behavioral hypothesis. People increase their contributions to public goods if they observe others are giving as well. ${ }^{3}$ This result could be found in laboratory experiments (e.g. Keser and van Winden, 2000;

\footnotetext{
${ }^{1}$ The question is relevant for other public goods and information on how many others vote, litter, evade taxes, behave in a criminal way, donate to charities, etc.

${ }^{2}$ People might also take other people's contributions as a signal for the quality of the public good or/and the charity providing it (e.g. Vesterlund, 2003; Potters, Sefton and Vesterlund, 2004).

${ }^{3}$ In a number of laboratory experiments, the information about others is varied, e.g. people receive feedback on either the average or minimum contribution of the group. The result show that people react stronger if individualized information is given (Sell and Wilson, 1991; Carpenter, 2004; Jones and McKee, 2005) and try to match the average contribution rather than the minimum or maximum contribution (Croson, 1998).
} 
Fischbacher, Gächter and Fehr, 2001) and more recently in natural field experiments (e.g. Frey and Meier, 2004a; Heldt, 2005; Shang and Croson, 2005). ${ }^{4}$ With respect to the two examples above, one would expect more people to contribute if they are informed that many people contribute to supporting the NPR.

(2) Framing and Conditional Cooperation. The two pieces of information given differ also in their framing on either the people who do not contribute or on the people who do contribute. The behavioral predictions whether framing either on contributors or non-contributors should matter are not clear. According to a simple theory of conditional cooperation, framing should not matter. As discussed above, people care about the average behavior in their reference group and change their behavior in line with its average behavior. The presentation of this information should not affect people's tendency to behave conditionally cooperative.

Framing on contributors or non-contributors might, however, affect people's behavior if the information about the behavior of others includes more than just the average behavior of the reference group. ${ }^{5}$ Inferring from the descriptive norm what the injunctive norm is might be affected by framing on cooperators or defectors. Reno et al. (1993) showed that indeed the injunctive norm is more important than the actual average behavior. They show that if people are focused on the injunctive norm (what is socially approved), the descriptive norm (what people do) becomes less important. The framing on either contributors or noncontributors, and therefore the shift of the focus of the descriptive norm, might influence the perception of the injunctive norm. Informing people about noncontributors might signal the injunctive norm that contributing is the appropriate behavior. If this is the case, the exact number of non-contributors becomes less important.

\footnotetext{
${ }^{4}$ For a review of the literature, see Gächter (2005). Another natural field experiment that can be interpreted as evidence for 'conditional cooperation' is presented by List and Lucking-Reiley (2002). The authors analyze the impact of 'seed money' on charitable donations. To increase the 'seed money' exogenously (which can be interpreted as donations by others) from 10 to 67 percent, increases donations by a factor of six, with a corresponding effect on both participation rates and contribution levels. This result shows a positive correlation between the giving of others and the giving of the individual donor. See also Andreoni and Scholz (1998) for a field study on interdependent preferences in charitable giving. A number of field experiments analyze how to foster charitable giving (e.g. Carpenter, Holmes and Matthews, 2004; Falk, 2004; Eckel and Grossman, 2005; Meier, 2005a).

${ }^{5}$ Fleishman (1988) finds even that the frame of the decision situation changes the sign of the correlation. In his laboratory experiment, a social dilemma framed as taking from a collective good leads people to conform to others' behavior, whereas framing it as giving to a public good leads people to even act contrary to others' behavior.
} 
Similarly, research in behavioral decision-making shows that omissions are quite differently perceived to commissions. For example, actively hurting somebody is much worse than passively not preventing that somebody gets hurt. Although both types of behavior lead to the same outcome the latter is perceived less bad (see, e.g. Baron and Ritov, 1994). One reason for such an 'omission bias' is that "the affective response to an event is enhanced if its causes are abnormal" (Kahneman and Miller, 1986: 145). Acts of commission are perceived as 'abnormal' because it is easier to imagine abstaining from an action. In the case of contributions to a public good the effect of framing depend on whether contributing or non-contributing is perceived as normal. If contributing is perceived 'normal' focusing on the number of non-contributors might stimulate a stronger overall reaction than focusing on the number of contributors, and vice versa.

Although it has been shown that framing effects are important in contribution to public goods (e.g. Andreoni, 1992; Sonnemans, Schram and Offerman, 1998), empirical evidence is completely lacking on whether focusing on the number of cooperators or defectors matters. But to know the influence of framing on conditional cooperation is important, on the one hand, in order to get a better notion of how people process the information about the behavior of others and, on the other hand, to inform fundraisers (e.g. from NPR) about potential behavioral effects of framing the information about the behavior of others.

This paper analyzes a framing effect in a natural field experiment. ${ }^{7}$ Students at the University of Zurich are asked each semester whether they want to contribute to two social funds. In the natural field experiment, students are randomly informed that many other students contribute (64 percent of the student population) to the two funds or that few other students contribute (46 percent). As this information is either based on the average over the last ten years (the lower contribution rate) or the behavior in the previous semester (the high contribution rate), no deception was involved. Frey and Meier (2004a) show in their analysis of these treatments of the natural field experiment that people increase their prosocial behavior if faced with many other students who do the same. The main contribution of this paper is to analyzing the effect of framing the same information differently. Another 2000 students were either informed that few don't contribute (36 percent) or that many don't contribute (54 percent).

The results of the study show that people increase their contribution when faced with many others who contribute, regardless of whether the information is framed on contributors or non-contributors. Unlike other studies, which find

\footnotetext{
${ }^{6}$ Other studies framed social dilemmas either as a public good or a common pool game and found substantial behavioral differences (Brewer and Kramer, 1986; Sonnemans, et al., 1998).

${ }^{7}$ For a taxonomy and a great survey on field experiments, see Harrison and List (2004).
} 
considerable framing effects, framing on non-contributors vs. contributors does not override conditional cooperation or social comparison effects. The correlation between group behavior and individual behavior, however, becomes weaker if people are informed about the number of non-contributors.

In addition, the paper investigates whether male and female students differ in their reaction to framing effects in social comparison. This question is important in isolating under which conditions men or women behave more or less pro-socially. This might explain seemingly contradictory results on gender differences in pro-social behavior (for an excellent survey, see Croson and Gneezy, 2005). The results of the natural field experiment show that male students seem to be more sensitive than female students to the behavior of others. In particular, in the positive framing, men react significantly stronger to other people's behavior than women (see also Meier, 2005b). In the negative framing, no gender difference can be detected.

The paper proceeds as follows: Section II presents the design of the natural field experiment. Section III discusses the results. Section IV concludes.

\section{Design of Natural Field Experiment}

Each semester, all the students at the University of Zurich have to decide whether or not they want to contribute to two official social funds - in addition to the compulsory tuition fee. On the official letter for renewing their registration, the students are asked whether they want to voluntarily give a specific amount of money (CHF 7.-, about US\$ 4.20) to a fund which offers cheap loans to students in financial difficulties and/or a specific amount of money (CHF 5.-, about US\$ 3) to a second fund supporting foreigners who study at the University of Zurich. Without their explicit consent (by marking a box), students do not contribute to any fund at all. The panel data is composed of the decisions of all students for the nine semesters since the winter semester $1998 / 99 .{ }^{8}$ From now on, I refer to the period in which the experiment was undertaken as period $t$, and the periods before that are referred to as period $t-1, t-2, t-3$, etc.

The natural field experiment was implemented in the naturally occurring decision situation at the University of Zurich. In the experimental intervention, 4000 subjects of the student population were selected at random and provided with additional information about the two funds. With the official letter for renewing registration and deciding whether to contribute to the two funds, the administration supplied the selected students with differing information about the behavior of other students. The sheet of paper that the various treatment groups

\footnotetext{
${ }^{8}$ For details on contribution to the two funds and an analysis of behavior over time, see Frey and Meier (2004b).
} 
received differed only with respect to the exact information given (see the appendix for a sample treatment sheet). Due to the 'institutional difference' that freshmen have to pick up the registration form at the counter of the administration office, only those students who have already registered, and therefore decided at least once in the past, are included in the treatment groups. As some students decided not to renew their registration, the decisions of the remaining 3488 students in the natural field experiment could be observed.

The natural field experiment provides the students with information about the behavior of others. 1000 students were provided with the information that a relatively high percentage of the student population (64\%) had contributed to the two funds in the past (Treatment 'High Pos.'), and a further 1000 students were provided with the information that a relatively low percentage $(46 \%)$ had contributed to the two funds in the past (Treatment 'Low Pos. '). No deception was used; the information provided was based on real contribution rates, but referred to different time periods. As contribution rates increase over time, the higher contribution rate applies to the previous term and the lower contribution rate indicates the average over the last ten years. ${ }^{9}$

Two additional treatments were undertaken in the natural field experiment in order to investigate whether the framing of the information about the behavior of others influences pro-social behavior. The information about average student contributions was therefore also framed negatively. In addition to the 2000 students who were in the two basic treatments, 1000 students received the information that a low percentage of the student population $(36 \%)$ did not contribute (treatment 'High Neg.'), and a further 1000 students received the information that a high percentage of the student population (54\%) did not contribute (treatment 'Low Neg.'), respectively. As some of the subjects did not renew their registration, the behavior of slightly less than 1000 students in each treatment group was observed.

Table 1 shows the summary statistics for the treatment groups. As the assignment was random, no significant differences emerged between the observable characteristics of subjects in the treatment groups. It is worth mentioning, however, that treatment groups differ slightly in their past donations, which indicates individuals' average donations in the semesters before the experimental period. The following analysis takes into account that individuals in the treatment groups differ in their past donation behavior by estimating individual fixed-effects.

\footnotetext{
${ }^{9}$ The different time periods were indicated on the information sheets by stating that either "...\% of the students contributed in the last semester" or "... \% of the students contributed in the last semesters."
} 
Table 1: Summary Statistics for Experimental Period

\begin{tabular}{lcccc}
\hline & $\begin{array}{c}\text { Treatment } \\
\text { 'High Pos.' }\end{array}$ & $\begin{array}{c}\text { Treatment } \\
\text { 'Low Pos.' }\end{array}$ & $\begin{array}{c}\text { Treatment } \\
\text { 'High Neg.' }\end{array}$ & $\begin{array}{c}\text { Treatment } \\
\text { 'Low Neg.' }\end{array}$ \\
\hline Age & 27.70 & 27.89 & 28.40 & 28.12 \\
& $(6.82)$ & $(6.79)$ & $(6.91)$ & $(7.30)$ \\
\# of semesters & 11.53 & 11.41 & 12.00 & 11.84 \\
& $(7.97)$ & $(8.29)$ & $(8.30)$ & $(8.99)$ \\
Gender (Female=1) & 0.49 & 0.52 & 0.55 & 0.53 \\
Ph.D. (=1) & 0.14 & 0.16 & 0.17 & 0.16 \\
Nationality (Foreigner=1) & 0.11 & 0.12 & 0.13 & 0.11 \\
Economist (=1) & 0.11 & 0.10 & 0.09 & 0.11 \\
Married (=1) & 0.09 & 0.11 & 0.11 & 0.12 \\
Past donations & 8.45 & 8.50 & 8.21 & 8.42 \\
& $(4.60)$ & $(4.60)$ & $(4.61)$ & $(4.72)$ \\
\# of observations & 878 & 876 & 870 & 864 \\
\hline
\end{tabular}

Notes: Standard deviations in parentheses.

Students decide anonymously at home about whether to contribute to the two social funds, but with different information about other students' behavior at their disposal. In a separate online questionnaire two years before undertaking the experiments, students were asked whether they talk with each other about the two funds. More than 75 percent of the students never talk with each other about the two funds. So we are not concerned that students would get to know about the different treatments. The analysis concentrates on contributions to at least one of the funds, although students have to decide whether or not to give to two different funds. Whether people contribute to at least one fund or not is used as a dependent variable, as it constitutes the lower limit of contribution.

The following analysis will look mainly at differences between the four treatment groups. As it cannot be excluded that already receiving an additional sheet (independent of the content) has an effect on people's contribution rate, comparing the behavior in the four treatments keeps everything but the contribution rate constant (even a potential placebo effect). The empirical question will be whether the willingness to contribute is higher if many others contribute (or few others do not contribute) compared to if few others contribute (or many others do not contribute). However, to get a sense of how behavior would have evolved if either students receive no treatment sheet or if students receive a sheet with 'neutral' information, we compare the behavior in the treatment conditions with behavior of all students not included in the experiment and 500 subjects who receive a treatment sheet with a 'neutral' information. Students receive the following information in the treatment 'Neutral Information': 
"The two funds support students from Switzerland and from around twenty countries from all continents. It enables them to study in Zurich." As this sheet includes no additional information it can be tested how such a neutrally framed information affects behavior compared to the information about the behavior of others.

\section{Analysis and Results}

The results are presented in two steps. First, the general effect of framing the behavior of others either as contributors or non-contributors is presented, and second, an analysis is made as to whether men and women differ in their reactions to the framed information about the behavior of others.

\subsection{Framing effect}

Figure 1 shows the change in the contribution rate (the proportion who contribute to at least one fund) in the treatment period, $t$, and the previous decision, $t-1$, for all four treatments. Looking first at the positive framing (treatments 'High pos.' and 'Low pos.'), the figure shows a positive correlation between the descriptive norm and people's own behavior, as shown in Frey and Meier (2004a). Students' contribution rate increases almost 1 percentage point from 76.36 to 77.11 percent if other members of their group also contribute. The contribution rate decreases almost 2 percentage points from 76.50 to 74.65 percent if students are faced with there being few other contributors. ${ }^{10}$ The difference is, however, not statistically significant ( $\mathrm{p}=0.11, \mathrm{t}$-test). In the negative framing (treatment 'High neg.' and 'Low neg.'), the effect is weaker. Students are still more likely to start contributing when only a few do not contribute (contribution rate increases almost 1 percentage point from 74.48 to 75.40 percent) than if many do not contribute (contribution rate increases around 0.2 percentage points from 75.68 to 75.87 percent). The difference is not statistically significant (n.s.). Even if people are informed about the number of non-contributors, they behave according to the theory of conditional cooperation. But the difference becomes smaller.

\footnotetext{
${ }^{10}$ As the probability of contributing decreases with every additional semester (Frey and Meier, 2004b), for subjects who did not receive any information about others' behavior, the contribution rate decreases around 3 percentage points between the two semesters.
} 
Figure 1: Change of Subjects' Own Behavior and Social Comparison

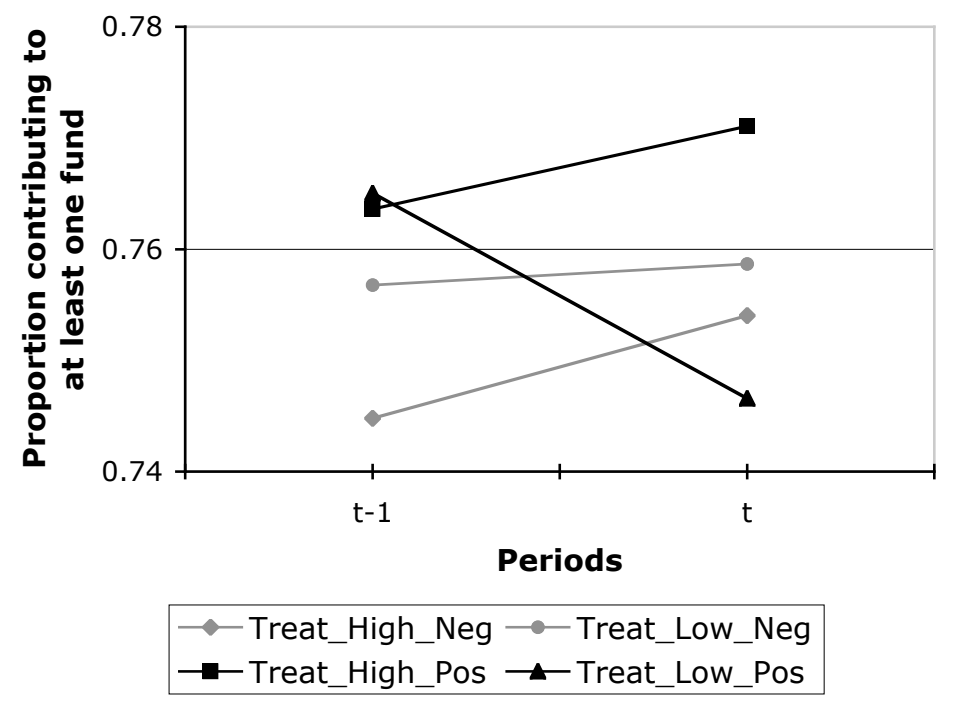

Table 2 presents a logit model with individual fixed-effects and robust standard errors adjusted for clustering on the individual level. The regression incorporates (and controls for) all nine semesters and is therefore able to better capture individual heterogeneity. The dichotomous dependent variable takes the value 1 if subjects contribute to at least one of the two funds and 0 otherwise. Column (1) presents the general effect of informing individuals that either many others or only few others contribute to the social funds - independent of the framing. The reference group consists of students who receive the information that relatively few contribute or many do not contribute (treatment 'Low pos.' and 'Low neg.'). The regression shows that people increase their contribution if surrounded by many others doing so. The difference is statistically significant at the 95 percent level. In line with the theory on conditional cooperation, people are willing to contribute to a public good if others do so as well - whether the information is framed positively or negatively.

Column (2) in table 2 shows the effects of all four treatments. The control treatment is the treatment 'Low pos.'. The results show that, compared to the control treatment, informing people about there being many contributors increases contributions. Looking at the positive framing, the difference is statistically significant at the 95 percent level. In the negative framing, contributions increase more if students are informed that there are few non-contributors ('High neg.') than that there are many non-contributors ('Low neg.'), which is in line with conditional cooperation. However, the difference is smaller than in the positive 
framing and the two coefficients are not statistically different from each other $\left(\chi^{2}(1)=0.77 ; \mathrm{p}<0.38\right)$.

Table 2: Social Comparison and Framing

\begin{tabular}{|c|c|c|}
\hline & (1) & (2) \\
\hline Treatment 'High Pos./Neg.' & $\begin{array}{c}0.289 \\
(2.23)^{*}\end{array}$ & \\
\hline Treatment 'Low Pos./Neg.' & Ref. group & \\
\hline Treatment 'High Pos.' (64\%) & & $\begin{array}{c}0.425 \\
(2.30)^{*}\end{array}$ \\
\hline Treatment 'Low Pos.' (46\%) & & Ref. group \\
\hline Treatment 'High Neg.' (36\% not) & & $\begin{array}{c}0.429 \\
(2.36)^{*}\end{array}$ \\
\hline Treatment 'Low Neg.' (54\% not) & & $\begin{array}{c}0.271 \\
(1.46)\end{array}$ \\
\hline Individual fixed effects & included & included \\
\hline Semester dummies & included & included \\
\hline \# of observations & 9,908 & 9,908 \\
\hline \# of individuals & 1,425 & 1,425 \\
\hline Log likelihood & -3720.2205 & -3719.093 \\
\hline $\begin{array}{l}\text { Notes: Dichotomous dependent variab } \\
\text { Coefficients of logit models. } z \text {-value in } \\
\text { for clusters in individuals. } \\
\text { Level of significance: } * 0.01<p<0.05 \text {, } * *\end{array}$ & $\begin{array}{l}\text { Contribution to } \\
\text { ntheses. Robus }\end{array}$ & $\begin{array}{l}\text { one fund }(=1) \\
\text { errors adjustec }\end{array}$ \\
\hline
\end{tabular}

The behavior of subjects receiving information about the behavior of others can be compared to the respective behavior of students who were not included in the experiment or those who received neutral information on the same information sheet (see Table 3). Compared to the control group who did not receive information about the behavior of others, the probability to contribute to the two funds increases if students are informed about a 'High' contribution rate. The contribution rate increases whether people are informed about many contributors ('High pos.') $(p<0.01)$ or few non-contributors ('High neg.') $(p<0.01)$. However, contribution rate do not differ if people are informed about a 'Low' contribution rate - independent of the framing. In sum, the probability to contribute is not decreased by informing about a few others who contribute but the probability increases if informed about many others who contribute. Subjects' behavior in the 'neutral' treatment does not differ from the behavior of subjects who do not receive any additional sheet at all. This can be interpreted that the treatment sheet 
in itself does not have much effect on contribution rate. The increase in contributions if informed about many others contributing is therefore mainly due to the high number of contributors (few non-contributors). As the coefficients are difficult to interpret in a logit model with fixed-effects, we calculated marginal effects in a probit model taking average donations in the past into account. The results show that the probability increases 4.5 percentage points if people are informed about a 'high' contribution rate compared to the control group who did not receive any information.

Table 3: Treatment effects and control groups

\begin{tabular}{|c|c|c|}
\hline & (1) & (2) \\
\hline Treatment 'High Pos./Neg.' & $\begin{array}{l}0.411 \\
(4.23)^{* *}\end{array}$ & \\
\hline Treatment 'Low Pos./Neg.' & $\begin{array}{c}0.122 \\
(1.23)\end{array}$ & \\
\hline Treatment 'High Pos.' (64\%) & & $\begin{array}{c}0.409 \\
(3.04)^{* *}\end{array}$ \\
\hline Treatment 'Low Pos.' (46\%) & & $\begin{array}{l}-0.016 \\
(-0.12)\end{array}$ \\
\hline Treatment 'High Neg.' (36\% not) & & $\begin{array}{c}0.414 \\
(3.17)^{* *}\end{array}$ \\
\hline Treatment 'Low Neg.' (54\% not) & & $\begin{array}{c}0.256 \\
(1.89)\end{array}$ \\
\hline Treatment 'Neutral Information' & $\begin{array}{c}-0.085 \\
(-0.44)\end{array}$ & $\begin{array}{c}-0.085 \\
(-0.44)\end{array}$ \\
\hline Control: 'Not included in experiment' & Ref. group & Ref. group \\
\hline $\begin{array}{l}\text { Individual fixed effects } \\
\text { Semester dummies }\end{array}$ & $\begin{array}{l}\text { included } \\
\text { included }\end{array}$ & $\begin{array}{l}\text { included } \\
\text { included }\end{array}$ \\
\hline \# of observations & 42,474 & 42,474 \\
\hline \# of individuals & 6,077 & 6,077 \\
\hline Log Likelihood & -16023.993 & -16022.856 \\
\hline
\end{tabular}

The result of the natural field experiment shows that people behave like conditional cooperators, regardless of whether the information about the behavior of others is framed on the number of contributors or on the number of noncontributors. However, if people are informed about the number of non- 
contributors, the positive reaction to the average group behavior becomes weaker and insignificant. The focus on non-contributors seems to change the effectiveness of the signal about the social norm.

The limited effect of framing on either contributors or non-contributors on conditional cooperation supports the hypothesis that people seem to care about the number of contributors and are able to process also the more complicated information about the number of non-contributors in the same way as the number of contributors. It is important to know that framing in such a situation does not seem to matter although we know that, on the one hand, people might react quite emotionally if confronted with defectors (Fehr and Fischbacher, 2004), and that, on the other hand, framing has substantial effects in other situations (e.g. Andreoni, 1992). Two potential reasons might be responsible for framing to have a limited effect. First, students react to high contributions rate by increasing their contributions compared to the control group who did not receive additional information while they do not reduce contributions when informed about a low contributions rate. The lack of an erosion of contributions in general might explain why they don't seem to react stronger to a framing on non-contributors. The emotional reactions after informed about a 'low' contribution rate seem to be not so strong. This might be due to either the relative modest 'low' contributions rate in the natural field experiment or that not contributing is not considered as violating the norm. Second, in the case of contribution to the social funds, students seem to have less of a prior or reference point about contributions to the funds. Their perception of the social norm is therefore not affected by focusing on the number of defectors and the equivalent number of cooperators. In the experiment of Andreoni (1992), however, the frame does trigger the feeling that doing something good is better than not doing something bad. There seem to be a prior which changes the behavior depending on the positive or negative frame.

The evidence of this natural field experiment give confidence that people correctly process the information that many others contribute independent of the framing and change their behavior accordingly.

\subsection{Gender effect}

Figure 2 shows how men and women react to the information about the behavior of others. The two panels show, with separate results for male and female students, the change in behavior in the four treatments between the period before the natural field experiment, $t-1$, and the period in which people received the information about the behavior of others, $t$. 


\section{Figure 2: Gender and Social Comparison}

Figure 2a: Men and Social Comparison

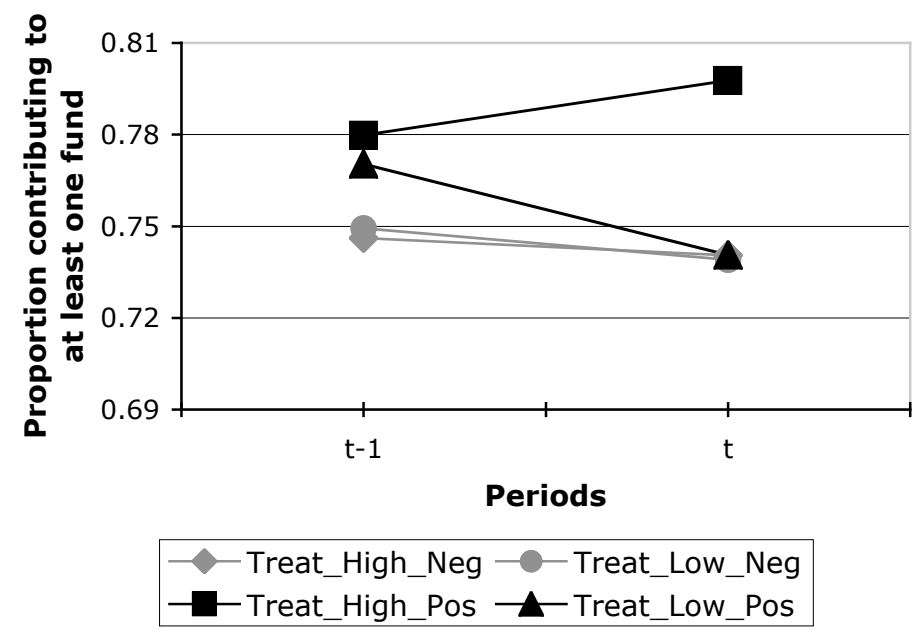

Figure 2b: Women and Social Comparison

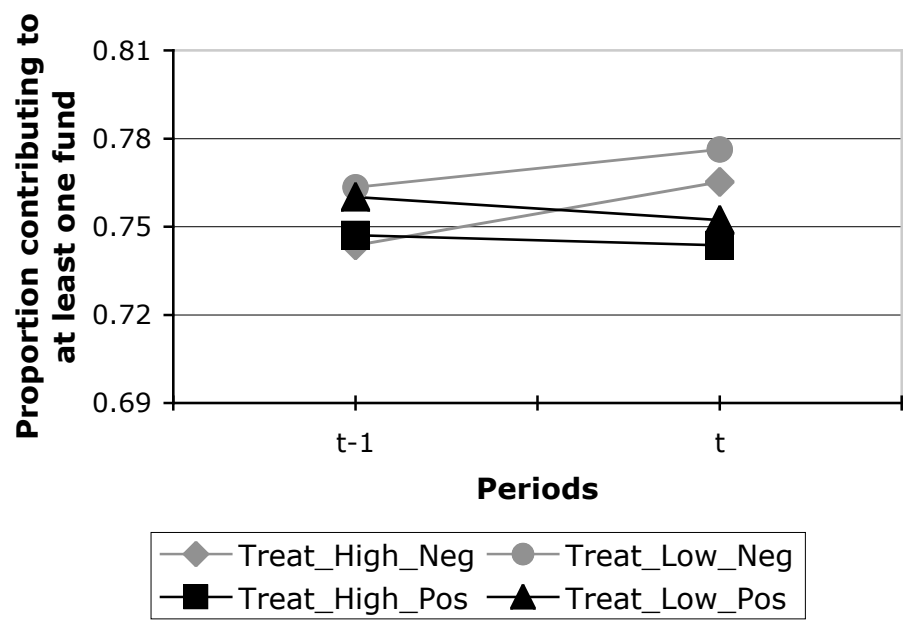

Figure $2 \mathrm{a}$ and figure $2 \mathrm{~b}$ show that men and women seem to react differently to receiving information about other people's behavior. Two differences are worth mentioning. First, male students seem to have a stronger reaction to receiving information about the behavior of others. The changes between period $t-1$ and $t$ 
are greater for male students than for female students. Second, male students' behavioral reaction to the behavior of others seems especially to differ in the positive framing. Being faced with many compared to few others contributing seems to have a significant behavioral impact (Meier, 2005b). The contribution rate increases from 78 percent to 80 percent when students are faced with many others $(64 \%)$ contributing. The contribution rate, however, drops from 77 percent to 74 percent when students are faced with few others (46\%) contributing. The reaction to the information in the negative framing is much smaller for male students. On the other side, female students' willingness to contribute seems to increase, in particular after receiving information about the number of noncontributors. The change in behavior is still higher when female students are informed that few others do not contribute, but it is smaller compared to male students.

Table 4 shows logit regressions with fixed effects, taking into account all previous semesters. The dependent variable is whether subjects contributed to at least one of the funds $(=1)$ or not $(=0)$. As in table 2 , the regression shows for men in column (1) and for women in column (3) the general behavioral effect of receiving the information that many others contributed to the two funds independent of the framing effect. The reference group consists of students who received the information that few others contribute or many others do not contribute. The results show that both male and female students are more likely to contribute to the two funds when faced with many others contributing. Both men and women seem to react like conditional cooperators. The behavioral reaction is, however, much greater for male students than for female students. The difference is statistically significant at the 95 percent level for male students. But for female students, the difference is not statistically significant at any conventional level.

Column (2) and column (4) show the reaction of men and women to the different treatments. Subjects in treatment 'Low pos.' constitute the reference group. While, for both sexes, the willingness to contribute increases more in both framings if faced with a high contribution rate, male students in particular react when informed about the number of contributors, while female students in particular react when informed about the number of non-contributors. Compared to the control group, male students' willingness increases most when faced with there being many other contributors $(\mathrm{p}<0.01)$, while female students' willingness increases most when faced with there being few non-contributors $(p<0.1)$. Comparing the coefficients within either the positive or the negative framing, and for the male and female sexes separately, only the difference between Treatment 'High Pos.' and Treatment 'Low Pos.' is statistically significant for male students 
$(\mathrm{p}<0.01) .{ }^{11}$ Column (5) presents a test for the whole sample interacting the treatment variables with a gender dummy (female equals 1). The results show that indeed men are significantly more sensitive to others behavior in the positive frame $(\mathrm{p}<0.05)$. The differences in the negative frame are not statistically significant.

Table 4: Social Comparison and Gender

\begin{tabular}{|c|c|c|c|c|c|}
\hline & \multicolumn{2}{|c|}{ Men } & \multicolumn{2}{|c|}{ Women } & \multirow{2}{*}{$\begin{array}{l}\text { All } \\
(5)\end{array}$} \\
\hline & (1) & (2) & (3) & (4) & \\
\hline Treatment 'High Pos./Neg.' & $\begin{array}{c}0.443 \\
(2.34)^{*}\end{array}$ & & $\begin{array}{r}0.161 \\
(0.91)\end{array}$ & & \\
\hline Treatment 'Low Pos./Neg.' & Ref. & & Ref. & & \\
\hline $\begin{array}{l}\text { Treatment 'High Pos.' } \\
(64 \%)\end{array}$ & & $\begin{array}{l}0.802 \\
(3.00)^{* *}\end{array}$ & & $\begin{array}{r}0.100 \\
(0.38)\end{array}$ & $\begin{array}{c}0.796 \\
(3.10)^{* *}\end{array}$ \\
\hline $\begin{array}{l}\text { Treatment 'Low Pos.' } \\
(46 \%)\end{array}$ & & Ref. & & Ref. & Ref. \\
\hline $\begin{array}{l}\text { Treatment 'High Neg.' } \\
(36 \% \text { not })\end{array}$ & & $\begin{array}{r}0.367 \\
(1.39)\end{array}$ & & $\begin{array}{r}0.469 \\
(1.87)\end{array}$ & $\begin{array}{r}0.363 \\
(1.37)\end{array}$ \\
\hline $\begin{array}{l}\text { Treatment 'Low Neg.' } \\
(54 \% \text { not })\end{array}$ & & $\begin{array}{r}0.267 \\
(0.99)\end{array}$ & & $\begin{array}{r}0.279 \\
(1.10)\end{array}$ & $\begin{array}{r}0.264 \\
(0.98)\end{array}$ \\
\hline Gender * ‘High Pos.' & & & & & $\begin{array}{l}-0.587 \\
(-2.28)^{*}\end{array}$ \\
\hline Gender * 'Low Pos.' & & & & & $\begin{array}{r}0.111 \\
(0.42)\end{array}$ \\
\hline Gender * 'High Neg.' & & & & & $\begin{array}{r}0.217 \\
(0.86)\end{array}$ \\
\hline Gender * 'Low Neg.' & & & & & $\begin{array}{r}0.125 \\
(0.48)\end{array}$ \\
\hline Individual fixed effects & Yes & Yes & Yes & Yes & Yes \\
\hline Semester dummies & Yes & Yes & Yes & Yes & Yes \\
\hline \# of observations & 4,670 & 4,670 & 5,238 & 5,238 & 9,908 \\
\hline \# of individuals & 664 & 664 & 761 & 761 & 1,425 \\
\hline Log likelihood & -1738.06 & -1736.21 & -1978.41 & -1976.60 & -3715.96 \\
\hline
\end{tabular}

Notes: Dichotomous dependent variable: Contribution to at least one fund $(=1)$. Coefficients of logit models. z-value in parentheses. Robust standard errors adjusted for clusters in individuals. Gender equals 1 for female and 0 for male. Ref. indicates the reference group.

Level of significance: $* 0.01<\mathrm{p}<0.05, * * \mathrm{p}<0.01$

\footnotetext{
${ }^{11}$ The $\chi^{2}$-tests for the differences of the coefficient show the following results. For male students: the difference between treatment 'High neg.' and 'Low neg. ': $\chi^{2}(1)=0.13, p=0.7$. For female students: the difference between treatment 'High neg.' and 'Low neg. ': $\chi^{2}(1)=0.63, p<0.43$.
} 
Both, men and women, react to the information about the behavior of others in line with conditional cooperation. The willingness to contribute increases for both sexes if faced with a high contribution rate. However, male students seem to be more sensitive to the behavior of others. Especially in the positive framing, men's willingness to contribute is positively correlated with the average group behavior. Female students' behavior has a much weaker correlation with the average group behavior. One possible explanation for the gender differences in the correlation between individuals' behavior and group behavior might be the relative importance of the larger group for men than for women. Results in social psychology claim that men identify more with the larger group than women do. Women, on the other hand, care more about close friends (Baumeister and Sommer, 1997; a countervailing perspective is presented in Cross and Madson, 1997; Gabriel and Gardner, 1999). Whether gender differences in the reference group explain the different reaction to the behavior of others remains, however, an open question and needs further investigation.

\section{Concluding Remarks}

The results of the natural field experiment show that students' willingness to behave pro-socially increases if many others in the group behave pro-socially. Whether people are informed about the number of contributors or the number of non-contributors, they exhibit conditional cooperative behavior. Framing has only a limited effect in the context studied. However, if the focus is on noncontributors, the correlation between average group behavior and individual behavior become weaker.

A detailed analysis of gender differences shows that men seem, in general, to be more sensitive than women to group behavior. In particular, if informed about the number of contributors, male students' willingness to behave prosocially correlates stronger with the group behavior than female students' willingness.

The results are important, as they show that in a field setting conditional cooperative behavior is relatively robust to framing effects. As we know that framing might have considerable behavioral consequences, the results instill more confidence in the behavioral regularity observed in other lab and field studies. However, these results need, on the one hand, to be replicated, not only for other public goods, but also for different levels of contributions. The results show that some quantitative differences emerge due to the framing. Future studies have to show whether this is a robust finding and, if so, what drives the difference. On the other hand, the results of the natural field experiments are inconclusive about what drives people to care about other people's behavior. Future studies in the field and/or in the lab should concentrate on trying to disentangle which 
motivational factors are responsible for the correlation between group behavior and individual behavior.

\section{Appendix}

Figure A.1: Sample Treatment Sheet

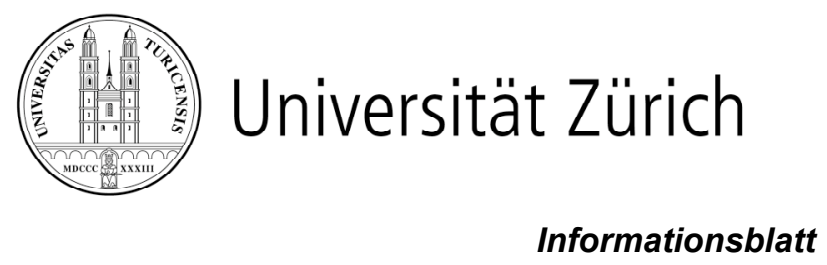

Wir möchten Ihnen dieses Semester Informationen zu den freiwilligen Beiträgen für die beiden Fonds ,Stiftung Darlehenskasse der Studentenschaft' (CHF 7.-) und ,Solidaritätsfonds für ausländische Studierende' (CHF 5.-) zukommen lassen:

\section{$64 \%$ aller Studierenden zahlten im letzten Semester in die beiden Fonds ein.}

\section{References}

Andreoni, James (1992). "Warm-Glow Versus Cold-Prickle: The Effects of Positive and Negative Framing in Cooperation in Experiments." Quarterly Journal of Economics 60(1), pp. 1-21.

Andreoni, James and Scholz, John Karl (1998). "An Econometric Analysis of Charitable Giving with Interdependent Preferences." Economic Inquiry 36(3), pp. 410-28.

Baron, Jonathan and Ritov, Ilana (1994). "Reference Points and Omission Bias." Organizational Behavior and Human Decision Processes 59, pp. 475-98.

Baumeister, Roy F. and Sommer, Kristin L. (1997). "What Do Men Want? Gender Differences and Two Spheres of Belongingness: Comment on Cross and Madson (1997)." Psychological Bulletin 122(1), pp. 38-44. 
Meier: Does Framing Matter for Conditional Cooperation?

Bohnet, Iris and Cooter, Robert D. (2004). "Expressive Law: Framing or Equilibrium Selection?" Mimeo, Kennedy School of Government, Harvard University.

Brewer, Marilynn B. and Kramer, Roderick M. (1986). "Choice Behavior in Social Dilemmas: Effects of Social Identity, Group Size, and Decision Framing." Journal of Personality and Social Psychology 50(3), pp. 54349.

Carpenter, Jeffrey (2004). "When in Rome: Conformity and Provision of Public Goods." Journal of Socio-Economics 33(4), pp. 395-408.

Carpenter, Jeffrey; Holmes, Jessica and Matthews, Peter Hans (2004). "Charity Auctions: A Field Experimental Investigation." Mimeo, Middlebury College.

Cialdini, Robert B.; Reno, Raymond R. and Kallgren, Carl A. (1990). "A Focus Theory of Normative Conduct: Recycling the Concept of Norms to Reduce Littering in Public Places." Journal of Personality and Social Psychology 58, pp. 1015-26.

Clotfelter, Charles T. (1997). "The Economics of Giving," J. W. Barry and B. V. Manno, Giving Better, Giving Smarter. Washington, D.C.: National Commission on Philantropy and Civic Renewal, 31-55.

Croson, Rachel (1998). "Theories of Commitment, Altruism and Reciprocity: Evidence from Linear Public Good Games." Mimeo, Wharton School, University of Pennsylvania.

Croson, Rachel and Gneezy, Uri (2005). "Gender Differences in Preferences." Mimeo, Wharton School, University of Pennsylvania.

Cross, Susan E. and Madson, Laura (1997). "Models of the Self: Self-Construals and Gender." Psychological Bulletin 122(1), pp. 5-37.

Eckel, Catherine C. and Grossman, Philip J. (2005). "Subsidizing Charitable Contributions: A Field Test Comparing Matching and Rebate Subsidies." Mimeo, Virginia Polytechnic Institute and Station University. 
Falk, Armin (2004). "Charitable Giving as a Gift Exchange: Evidence from a Field Experiment." Mimeo, Institute for Empirical Research in Economics, University of Zurich.

Fischbacher, Urs; Gächter, Simon and Fehr, Ernst (2001). "Are People Conditionally Cooperative? Evidence from a Public Goods Experiment." Economics Letters 71(3), pp. 397-404.

Fleishman, John A. (1988). "The Effects of Decision Framing and Others' Behavior on Cooperation in a Social Dilemma." Journal of Conflict Resolution 32(1), pp. 162-80.

Frey, Bruno S. and Meier, Stephan (2004a). "Social Comparisons and Pro-Social Behavior: Testing Conditional Cooperation in a Field Experiment." American Economic Review 94(5), pp. 1717-22.

(2004b). "Pro-Social Behavior in a Natural Setting." Journal of Economic Behavior and Organization 54(1), pp. 65-88.

Gabriel, Shira and Gardner, Wendi L. (1999). "Are There "His" and "Hers" Types of Interdependence? The Implications of Gender Differences in Collective Versus Relational Interdependence for Affect, Behavior, and Cognition." Journal of Personality and Social Psychology 77(3), pp. 642-55.

Gächter, Simon (2005). "Conditional Cooperation in the Field and the Lab: Behavioural Findings and Policy Implications." Mimeo, University of Nottingham.

Harrison, Glenn W. and List, John A. (2004). "Field Experiments." Journal of Economic Literature XLII, pp. 1009-55.

Heldt, Tobias (2005). "Conditional Cooperation in the Field: Cross-Country Skiers' Behavior in Sweden." Mimeo, Uppsala University.

Jones, Michael and McKee, Michael (2005). "Feedback Information and Contributions to Not-for-Profit Enterprises: Experimental Investigations and Implications for Large-Scale Fund-Raising." Public Finance Review 32(5), pp. 512-27.

Kahneman, Daniel and Miller, D. T. (1986). "Norm Theory: Comparing Reality to Its Alternative." Psychological Review 93, pp. 136-53. 
Keser, Claudia and van Winden, Frans (2000). "Conditional Cooperation and Voluntary Contributions to Public Goods." Scandinavian Journal of Economics 102(1), pp. 23-39.

List, John A. and Lucking-Reiley, David (2002). "The Effects of Seed Money and Refunds on Charitable Giving: Experimental Evidence from a University Capital Campaign." Journal of Political Economy 110(1), pp. 215-33.

Meier, Stephan (2005a). "Do Subsidies Increase Charitable Giving in the Long Run? Matching Donations in a Field Experiment," Mimeo. Institute for Empirical Research in Economics, University of Zurich.

(2005b). "Conditions under Which Women Behave Less/More Pro-Socially Than Men." Mimeo, Kennedy School of Government, Harvard University.

Potters, Jan; Sefton, Martin and Vesterlund, Lise (2004). "After You Endogenous Sequencing in Voluntary Contribution Games." Journal of Public Economics, Forthcoming.

Reno, Raymond R.; Cialdini, Robert B. and Kallgren, Carl A. (1993). "The Transsituational Influence of Social Norms." Journal of Personality and Social Psychology 64(1), pp. 104-12.

Sell, Jane and Wilson, Rich K. (1991). "Levels of Information and Contributions to Public Goods." Social Forces 70(1), pp. 107-24.

Shang, Jen and Croson, Rachel (2005). "Field Experiments in Charitable Contribution: The Impact of Social Influence on the Voluntary Provision of Public Goods." Mimeo, Wharton School, University of Pennsylvania.

Sonnemans, Joep; Schram, Arthur and Offerman, Theo (1998). "Public Good Provision and Public Bad Prevention: The Effect of Framing." Journal of Economic Behavior and Organization 34(1), pp. 143-61.

Vesterlund, Lise (2003). "The Informational Value of Sequential Fundraising." Journal of Public Economics 87(3-4), pp. 627-57. 
Copyright of Contributions to Economic Analysis \& Policy is the property of Berkeley Electronic Press and its content may not be copied or emailed to multiple sites or posted to a listserv without the copyright holder's express written permission. However, users may print, download, or email articles for individual use. 
Copyright of Contributions to Economic Analysis \& Policy is the property of Berkeley Electronic Press and its content may not be copied or emailed to multiple sites or posted to a listserv without the copyright holder's express written permission. However, users may print, download, or email articles for individual use. 
Copyright of Contributions to Economic Analysis \& Policy is the property of Berkeley Electronic Press and its content may not be copied or emailed to multiple sites or posted to a listserv without the copyright holder's express written permission. However, users may print, download, or email articles for individual use. 
Copyright of B.E. Journals in Economic Analysis \& Policy: Contributions to Economic Analysis \& Policy is the property of Berkeley Electronic Press and its content may not be copied or emailed to multiple sites or posted to a listserv without the copyright holder's express written permission. However, users may print, download, or email articles for individual use. 